\title{
PÄÄKIRJOITUS
}

\section{I-päivillä tavataan!}

\author{
Susanna Nykyri \\ Tampereen teknillisen yliopiston kirjasto \\ susanna.nykyri@tut.fi \\ https://orcid.org/0000-0002-5018-5176 \\ Asiasanat: DORA-julistus; Informaatiotutkimuksen päivät; toimitustyö
}

Tätä kirjoittaessa joka toinen vuosi järjestettävät kansalliset Informaatiotutkimuksen päivät eli I-päivät ovat ovella. Tällä kertaa järjestelyistä on kaunis kiittäminen Kristina Eriksson-Backaa ja Åbo Akademin Informaatiotutkimuksen oppiainetta. On tarpeellista, että alan oppiaineiden edustajille ja asiantuntijatehtävissä toimiville tarjoutuu mahdollisuus keskustella alan koulutuksesta ja tutkimuksesta sekä laajemminkin alan kehittämisestä ja eri ilmiöistä. Tällä kertaa tilaisuuden keynote-esitysten teemana on Phenomena related to information studies seen from outside the field (puhujina Mats Neovius ja Shahrokh Nikou). Työryhmiä on kymmenen:

- Humanismi ja informaatiotutkimus (vetäjinä Vesa Suominen, Pirjo Tuomi \& Jarmo Saarti)

- Knowledge Management (emerging trends) (vetäjinä Anna Suorsa \& Farhan Ahmad)

- Internetin lieveilmiöt ja verkon vaarat / The criminal and harmful content of the Internet (vetäjinä Ari Haasio \& Anu Ojaranta)

- Doctoral forum - Informaatiotutkimuksen väitöskirjahankkeet (vetäjinä Elina Late \& Sanna Kumpulainen)

- Yleisten kirjastojen osaamisvaatimukset ja koulutuksen vastaavuus (vetäjänä Ari Haasio)

- Informaatioalan yliopistokoulutus ja työelämätarpeet (vetäjinä Noora Hirvonen \& Susanna Nykyri)

Artikkeli on lisensoitu Creative Commons Nimeä-EiKaupallinen-JaaSamoin 4.o Kansainvälinen -lisenssillä

Pysyvä osoite: https://doi.org/10.23978/inf. 76065 
- Hälsoinformation och e-hälsa / Terveystieto ja e-terveys / Health information and e-health (vetäjinä Isto Huvila, Kristina Eriksson-Backa, Heidi Enwald, Noora Hirvonen \& Hai Nguyen)

- Avoin tiede ja avoin tieto (vetäjinä Mikael Laakso \& Susanna Nykyri)

- Erilaiset lukutaidot ja lukuharrastuksen monimuotoinen tukeminen / Divergent literacies and promotion of reading habits (Anu Ojaranta \& Siinamari Tikkinen)

- Information behaviour and information practices among minorities (Jannica Heinström, Eeva-Liisa Eskola \& Hilda Ruokolainen)

Aiheet eivät suinkaan kata kaikkia alamme tutkimussuuntauksia ja tarpeita, mutta ne kertovat silti alamme monipuolisuudesta - ja myös I-päivien suosiosta. Haluankin jo nyt osaltani lämpimästi kiittää kaikkia työryhmiä ideoineita ja valmistelleita, ja työryhmiin esityksiä tarjonneita!

Väistyvä toimitussihteerimme (2016-2018) Matti Lassila on jälleen tehnyt suuren ja erinomaisen työn toimittaessaan lehden aineistot julkaistaviksi. Uusi toimitussihteerimme (2019- ) Harri Ollikainen on rohkeasti tarttunut tiedetoimittamisen haasteisiin ollen mukana jo tämän numeron valmisteluissa.

Matti on ollut erittäin innokas ja taitava kehittämään lehden verkkoominaisuuksia ja hoitanut lehden toimittamisen vastuuntuntoisesti ja asiantuntevasti. Onkin hienoa, että hän on lupautunut jatkamaan lehden ja yhdistyksen teknisenä neuvonantajana jatkossakin. Matti - sydämellinen kiitos näistä antoisista yhteistyövuosista!

Seuraavan numeron eli Avoin tiede ja avoin tieto -teemanumeron vierailevana päätoimittajana toimivaa Mikael Laaksoa on myös erityisen lämpimästi kiittäminen. On helpottavaa ja ilahduttavaa, että seuraava numero on tätä julkaistaessa jo erittäin pitkällä ja tulee olemaan sisällöltään ansiokas ja mielenkiintoinen!

Edellä mainitussa numerossa tullaan julkaisemaan myös DORA-julistuksen (San Francisco Declaration on Research Assessment) suomennos, joka on jo nyt luettavissa DORAn sivuilla (2018). Allekirjoittanut on toiminut sen kääntäjänä ja saanut siihen arvokasta ja kaipaamaansa apua Maria Forsmanilta ja Anne Lehdolta. Heidän lisäkseen haluan kiittää erittäin lämpimästi myös Anna Hatchia (DORA) loistavasta yhteistyöstä!

Koko toimituskuntaa ja puheenjohtaja Noora Hirvosta kiitän mitä moninaisimmasta ja arvokkaasta avustanne lehden asioissa! Vertaisarvioijia ja muita käsikirjoituksia kommentoineita on jälleen kiittäminen rakentavista arvioistanne! Niitä on ollut ilo välittää!

Alamme ihmisten upeista työpanoksista huolimatta, joudun valitettavasti yhä toteamaan, että valitettavasti kotimaisten tiedelehtien piina ja kurimus 
kestävän avoimuuden mahdollistavan rahoitusmallin puuttuessa jatkuu. Toivoakseni Science Europen julkaiseman Plan S:n (2018) merkitys nähdään myös tässä yhteydessä - vaikeitakin ratkaisuja on kyettävä tekemään, jotta tiedejulkaisemisen avoimuus saadaan arkipäiväksi ja kotimaiset tiedelehtemme olisivat jo vuonna 2020 kattavasti ja reilusti avoimia!

Lukemisen, verkostoitumisen, vaikuttumisen ja vaikuttamisen iloa! Nähdään turuilla ja toreilla sekä verkossa!

Tampereella 25.10.2018

Susanna Nykyri

\section{Lähteet}

Dora Community. (2018). DORA-julistus (San Francisco Declaration on Research Assessment). https://sfdora.org/read/fi/. Alkuperäinen 2012. Suomennos Susanna Nykyri.

Science Europe. (2018). Plan S: Accelerating the transition to full and immediate Open Access to scientific publications. http://scieur.org/plan-s 